\title{
Global instability and the development project: is the twenty-first century different?
}

\author{
Jayati Ghosh* \\ Jawaharlal Nehru University, New Delhi, India
}

Despite a few pockets of relatively fast expansion, overall deficiency of demand characterises the world economy. The external stimulus provided by the US is declining; Europe's net impact is negative because of the emphasis on generating current-account surpluses. While China is already a significant global economic player, it cannot adequately counter the effect of this reduced impetus from the major developed countries. Much of the developing world is relying on unsustainable debt-driven bubbles in the financially liberalised environment to generate economic recovery. Sustaining the development project will require countries to shift from export-oriented growth to more reliance on domestic demand through wage and employment increases.

Keywords: world economy, financial instability, global trade, development

JEL codes: $B 50, F 40,011$

\section{GLOBAL CAPITALISM TODAY: UNSTABLE, MORIBUND, OR JUST RESTING?}

Ever since the global financial crisis of 2008-2009, the trajectory of the world economy has been hesitant, unstable and prone to many risks. Output recovery has been limited and fragile; and, more significantly, even in the more dynamic economies, it has not increased good-quality employment or reduced inequality and material insecurity. Global capitalism as an economic regime is increasingly unable to deliver on its own promise of continuous expansion within a largely stable society. Even so, discussions of the 'end' of capitalism still typically seem overstated and futile, not least because those hoping and mobilising for bringing in an alternative system are everywhere so scattered, weak and demoralised. In effect, capitalism remains the only game in town, which is why even in its current debilitated and even decrepit state, there are no rivals.

Indeed, it could be argued that the current difficulties of capitalism are not the result of any external threat or combined socio-political opposition to it, but because it has been too 'successful' for its own good, and so has to confront the contradictions generated by this 'success'. Contemporary globalised capitalism has managed to overrun and conquer its opponents or those that could restrain it (such as trade unions and other associations of workers that could reduce capital's bargaining power; democratic accountability working through regulatory structures that limit or constrain the activities and profits of capitalists and large corporations; expressions of collective concern voicing the requirements of the larger social good; and so on) to the point where it is now almost completely untrammelled. As a result, there are no checks and balances of the kind that in various periods in the past have generated both less economic volatility and more social stability within a broadly capitalist framework.

* Email: jayatijnu@gmail.com. 
In purely economic terms, this 'success' of capitalism in vanquishing its opponents means less expansion of demand for products that the system must keep coming up with in terms of its own logic. It also means less ability to create new sources of demand, as financialisation and credit bubbles also appear to have run their course, despite almost endless injections of synthetic liquidity through very loose monetary policy. In ecological terms it means the accelerated exploitation and degradation of nature, to the point where it is not merely irresponsible with respect to the future but actively damaging material conditions in the present. In socio-political terms, it means more widespread despair, alienation and individualised responses that threaten the very basis of functioning societies. In an almost textbook extension of the biological argument of the prey-predator relationship, it could be argued that capitalism as a system is in the process of killing off all its prey, to the point that its own existence could be threatened, even if not in the form of an 'overthrow', but simply by losing steam altogether.

This is most evident globally in the overall deficiency of demand that characterises the world economy, despite a few pockets of relatively fast expansion. The underlying causes of this aggregate demand deficiency have existed for some time, but they were disguised by credit-driven expansions that were inherently unsustainable. The boom that preceded the crash of 2008 could occur because (particularly in the United States, but also in parts of Europe and some emerging markets) wage stagnation that would have led to stagnant demand was countered by financialisation that enabled consumption to increase faster than the real incomes of the majority of workers. As has been widely argued (UN 2006; UNCTAD 2008; Ghosh 2010), the pattern of pre-global-crisis economic growth in both developed and developing countries suffered from several limitations, paradoxes and inherent fragilities. These ranged from economic imbalances to environmental constraints to social and political tensions and volatility emanating from increased inequalities. As is well known, in the US and other advanced economies, the boom was based on speculative practices enabled and encouraged by financial deregulation. It also drew recklessly on natural resources in a manner that has created a host of ecological and environmental problems, especially in the developing world. Even during the boom, despite aggregate employment increases, most paid work became more fragile and less secure, in both developed and developing countries. Furthermore, because its benefits were spread so unequally, most people in the developing world - even many in the most dynamic economic region of Asia - did not really gain from the boom.

From a purely macroeconomic perspective, in the 2000s the economic expansion of some large economies' demand was sustained by a combination of financial liberalisation and loose monetary policy that enabled households and companies to consume and invest beyond their means through borrowing. This then enabled some developing countries (especially in Asia, but subsequently across all developing regions) to expand on the basis of increased demand for their exports from the core capitalist countries. Therefore, almost all developing countries adopted an export-led growth model, requiring the containment of wage costs and domestic consumption for the sake of international competitiveness and growing shares of world markets. In a spectacularly irrational twist, this was accompanied by the net transfer of financial resources from the South to the North (BIS 2008; 2010; UNCTAD 2010; 2014; 2016) as more and more countries sought to achieve current surpluses and all developing regions sent their net savings to advanced economies, most of all to the United States. This was famously described by the then head of the US Federal Reserve, Ben Bernanke, as a 'savings glut', especially in Asia, but it could more properly be categorised as an investment famine, since it was typically associated with falling investment rates in the capital-exporting developing countries. The current-account imbalances that were subsequently seen as one of the 'causes' of the global crisis were in fact utterly 
necessary for the prior much-celebrated boom, which could not have occurred in that form otherwise.

Other than the current-account imbalances, which have since reduced or changed form, none of these problematic features of global capitalism has been fundamentally altered in the post-crisis scenario. This makes any current or future expansion just as vulnerable as it was before the global crisis erupted. Further, there seems to be little likelihood of widespread and coordinated implementation of macroeconomic policies that would generate more demand. The incredibly loose monetary policies in the advanced economies operated to keep them afloat for a while, and contrary to standard monetarist predictions thus far they have not generated significant inflationary pressures. But they have not managed to kickstart real recovery either. In any case, it is clear that they have run their course and are in the process of being revised. However, the more deregulated financial structures and systems that enabled speculative bubbles to develop and persist still remain. Post-crisis attempts to bring in appropriate regulation were extremely limited and even these are now sought to be dismantled in the US as well as in the EU, while any form of labour protection has become even more difficult than before. Meanwhile, ideological opposition to expansionary fiscal policy remains strong across most governments, even as the continued lobbying power of large corporations and moneyed elites prevents any substantial cross-country effort at raising tax revenues by curbing tax evasion and avoidance strategies. The absence (and lack of immediate prospect) of coordinated fiscal expansion across major countries, even to the limited extent that occurred in 2009 just after the global financial crisis, suggests that it would be difficult if not impossible for individual countries to 'go it alone' and indulge in expansion without prompting capital flight. Along with these concerns, there is now a real possibility of the eruption of trade wars, reminiscent of the interwar period of the twentieth century.

Therefore, it is evident that we are in a period of global capitalist stagnation and instability. This is already reflected in lower aggregate growth rates, with the world economy growing at an estimated average of 3.3 per cent per annum since 2008 , compared to 4.5 per cent in the period 2000 to $2007 .{ }^{1}$ GDP data are notoriously unreliable, as well as problematic, because they do not really capture crucial aspects of material life, but since capitalism is ultimately all about accumulation, aggregate income growth does provide some indication of capitalism's success in its own terms. This is obviously deficient at present.

The period during and since the Great Recession has also put paid to another myth that was widely held during the earlier boom: that of the 'decoupling' of growth in the developing world (particularly in some major emerging markets like China, India and Brazil) from that of the advanced economies. This optimistic assessment was based on what turns out to have been a relatively short period in the 2000 s, essentially from 2002 to 2008 , when the advanced economies grew at an average annual rate of only around 2 per cent, while the emerging market and developing countries showed higher as well as accelerating rates of GDP growth (Figure 1, overleaf). However, this turned out to be something of an aberration: the continued degree of dependence of the periphery on the capitalist core was reaffirmed during and after the global crisis. This originated in the United States and then spread to Europe - but also immediately affected the emerging markets in the developing world, even those with current-account surpluses and other signs of economic strength. Thereafter, GDP growth rates of these two categories of economies have moved broadly in tandem, with a sharper slowdown (from higher rates) evident for the emerging and developing economies.

This is bad news for development, since this expression of the exhaustion of advanced capitalism is occurring when in many parts of the world it is still far from reaching maturity, or even delivering the types of economic and social outcomes that residents of the

1. Based on calculations from data in IMF World Economic Outlook October 2017. 
10.

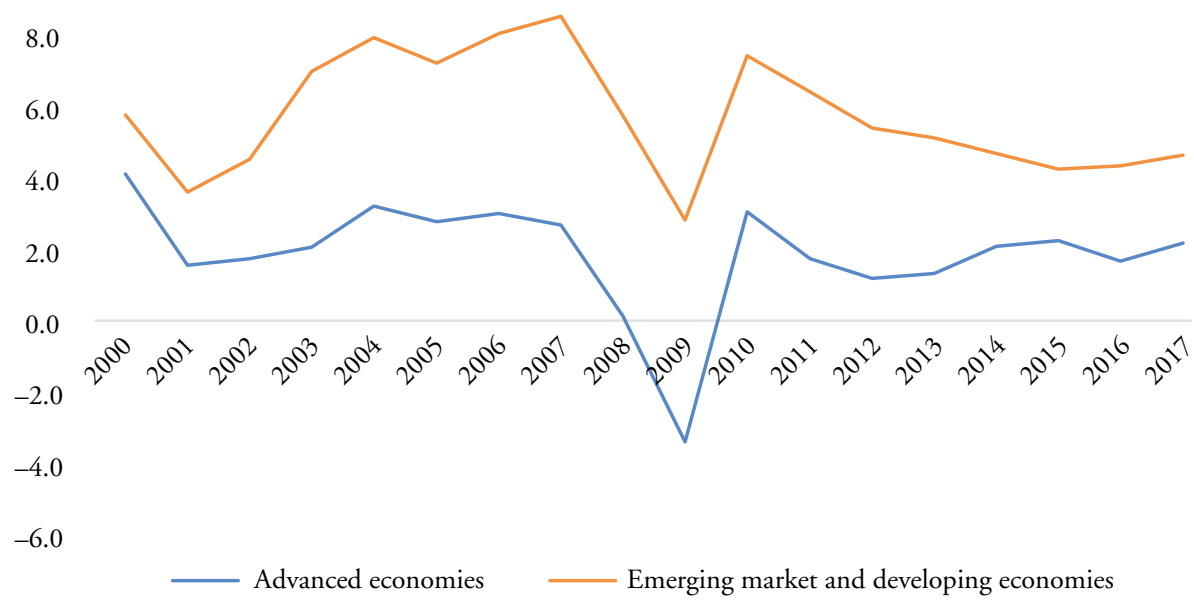

Source: Data from IMF World Economic Outlook 2017.

Figure 1 Real GDP growth (per cent per year)

advanced or developed countries have taken for granted across many decades. Even as the development project is nowhere near complete for much of the world's population, the apparent weakening of capitalist dynamism means that the previous method of achieving higher per capita incomes may not be available to most developing countries. In this conjuncture, an important question then becomes that of where the global demand can come from to ensure more GDP growth globally.

\section{GLOBAL DEMAND: AS ADVANCED ECONOMIES RETREAT, CAN CHINA TAKE UP THE SLACK?}

For several decades, the US economy functioned as the principal agent of global demand, sucking in vast amounts of imports from the rest of the world as it built up large currentaccount deficits. Of course, it was easily able to finance these deficits with capital inflows, benefiting from its status as the holder of the only viable global reserve currency. But just as the US was in effect able to make the rest of the world pay for its own domestic economic expansion, this expansion had positive effects on growth in the rest of the global economy. The US functioned as the primary source of demand for major exporting nations, thereby pulling much of the rest of the world economy along with it in the intermittent periods of boom. In the 1990s and again in the 2000s, there were prolonged periods during which the current-account deficits of the US grew and then remained at very high levels, generating demand for others in the world economy. While major exporting nations like Germany, China and to a lesser extent Japan were obviously the chief beneficiaries of this, the expansion trickled down to other countries and regions. As noted earlier, this method of global expansion was not ideal. It created imbalances that were bound at some point to become unsustainable, and possibly erupt in crises, as they indeed did in 2001 and again more severely in 2008-2009. Perhaps even more significantly, they reflected the irrational system 
in which poorer developing nations like China essentially financed rich economies like the USA to buy their export products.

However, since the global crisis, there has been an overall reduction in global imbalances, along with a change in their nature. The advanced economies as a group no longer provide a positive net demand stimulus to the rest of the global economy. The US economy's net stimulus to the rest of the world has been falling as its current-account deficits have been controlled. Other advanced economies, especially in Europe, have increased their currentaccount surpluses. Figure 2 shows that the huge current-account deficit of the advanced economies as a group, of more than $\$ 580$ billion in 2008 , shrank dramatically the following year. Thereafter, and especially since 2013, advanced economies have shown growing current-account surpluses, implying that they as a group no longer provide a net demand stimulus to the world economy. Meanwhile the group of developing, emerging and transition economies ran surpluses until 2014, which turned to net deficits thereafter. However, these deficits were much smaller in absolute size and were nowhere near large enough to counteract the impact of the declining net demand from the advanced economies. This global insufficiency of aggregate demand is what currently condemns the world economy to its 'new normal' of supposedly secular stagnation.

While the reduction in US deficits is obviously important, another significant change was in Germany, which since 2010 has been running the largest surpluses of any economy in the world. Furthermore, these surpluses have been increasing recently. This mercantilist approach of Germany imparts a severely negative impulse to global demand. As a large rich economy, Germany's insistence on internal wage and demand suppression has meant that productivity increases are not matched by wage increases. This necessarily implies relying fundamentally on external demand for its own expansion, thereby entering those markets and depriving those economies of potential economic activity. (Interestingly, other countries in the 'Teutonic bloc', such as Austria and the Netherlands, have behaved similarly.) But the adverse German influence may extend even further, since it has also been actively trying to remake the rest of the eurozone in its own image at least with respect to this feature, by forcing austerity policies upon the peripheral economies and squeezing current-account surpluses out of devastated economies in decline. The strategy is evidently to export

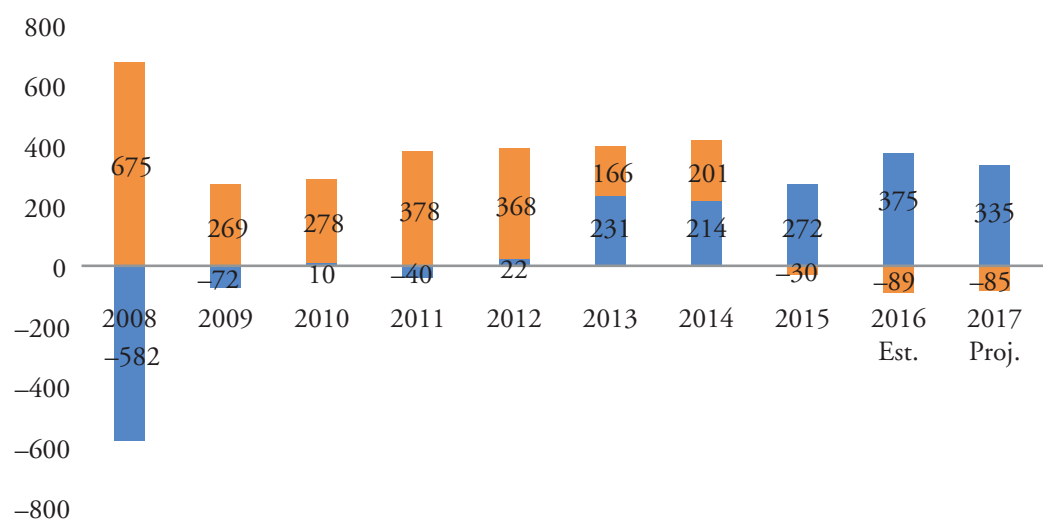

advanced economies $\quad$ Emerging and developing economies

Source: Data from IMF World Economic Outlook 2017.

Figure 2 Current-account balances (\$ bn) 
the eurozone's deflation and unemployment to the rest of the world. This is why even the eurozone outside Germany and the European Union as a whole have generated growing current-account surpluses since 2013. These surpluses have not been associated with faster output growth with more employment, since they have been based on wage suppression within these economies.

Indeed, while Chinese and aggregate Asian current-account surpluses are well known and much talked of, they have been much more variable and recently on a clearly declining path. Just before the global crisis in 2008, East Asian current-account surpluses amounted to around $\$ 650$ billion, while the European surplus economies were only around one-tenth of that. Thereafter, East Asian surpluses fell to less than $\$ 400$ billion by 2013 , and only recovered to the 2007 level a few years later. But the European surplus economies showed continuously increasing surpluses, especially from 2012, such that by 2017 they were around the same level as the East Asian surpluses, at around $\$ 600$ billion. $^{2}$

The recent German role in the global economy may be doubly pernicious. Unlike the Chinese expansion, which during the boom created more growth in a range of other developing countries by drawing them into the value chain for export to the advanced countries and has thereafter enabled significant infrastructure investment in many countries through capital flows in the form of foreign aid, cheap loans and direct investment, the German expansion has not had similar positive effects for most developing countries. In addition, by imposing macroeconomically repressive and mercantilist policies upon the rest of the eurozone, it is further adding to the negative stimulus imparted to the global economy.

The question arises: can the Chinese economy take up the slack by becoming another growth pole, effectively providing sufficient demand stimulus for a significant part of the global economy or at least the developing world? China already has the second-largest economy in the world and accounted for an estimated 36 per cent of global GDP growth (at market exchange rates) in the period 2009-2017. This contrasts with 26 per cent contribution to global growth by the United States and a near-zero but slightly negative contribution from the European Union. ${ }^{3}$ What may be even more significant is China's increasing significance in world trade. In 2013 China overtook the US to become the world's largest merchandise trader, and in 2014 it accounted for around 13 per cent of world merchandise exports (significantly more than the US share of less than 9 per cent) and 11 per cent of global imports (not much lower than the US share of 13 per cent). ${ }^{4}$ By 2015, China was the largest trading partner of at least 43 countries, compared to only 35 for which the US was the largest trading partner. ${ }^{5}$ It is among the top three trading partners for most countries across the world in terms of their imports, and a significant share of countries in terms of their exports.

Indeed, rapid growth in China was the most significant factor behind the growth acceleration in large parts of the developing world from 2002 onwards. By generating a wide set of global value chains that drew in raw materials and intermediate goods imports from large parts of the developing world across hemispheres to enable processing for export to the developed countries, China did play something of the role of lead goose in the muchdiscussed 'flying geese model'. For developing countries, this affected both volumes and values of merchandise exports. The ensuing expansion of trade was particularly beneficial for primary product exporters, who experienced significant terms-of-trade improvements. It is true that cheaper manufactured goods from China did flood markets not only in

2. Based on data from IMF World Economic Outlook September 2017.

3. Based on data from IMF World Economic Outlook September 2017.

4. $\quad$ Based on data from WTO World Trade Report 2017.

5. Based on data from WTO World Trade Report 2016 and IMF World Economic Outlook 2016. 
advanced countries but also across developing nations, affecting their rates and patterns of industrialisation, but the overall effect on income growth was definitely positive. As China's current-account surpluses led over time to the largest accumulation of foreign-exchange reserves that the world economy has yet seen, there were also moves on the capital account that benefited developing countries. China's aid, loans and FDI into emerging markets and developing countries began to dwarf the relatively small and declining contributions of advanced economies. A significant part of Chinese foreign aid (described as funds for development cooperation) was directed to infrastructure projects, especially in Southeast Asia, Latin America and Africa, and these had direct and indirect effects on growth prospects in the recipient countries. In addition, by 2014 the China Development Bank and the China Eximbank became among the most active development lenders, dwarfing traditional lenders like the World Bank with total loans of $\$ 1200$ billion and $\$ 300$ billion respectively, a significant part of which was directed to developing countries (UNCTAD 2015). Since the mid 2000s, Chinese direct and indirect financing of infrastructure investment in SubSaharan Africa has dominated over all other external players, including the G7 countries (Gutman et al. 2015). Unlike the foreign aid and capital flows from the Northern advanced economies, Chinese investment, aid and loans are overwhelmingly directed towards infrastructure expansion, particularly in the transport and energy sectors.

Such a pattern clearly suggests the potential for China to become a significant global economic player, but the question is whether its role will be substantial enough to counter the reduced impetus from the major developed countries. On this question, several points must be noted. First, despite its recent rapid growth and current importance in the global economy and in global trade, China is still very much a developing economy, with per capita income only around 15 per cent of the US per capita income at market exchange rates, and total size of economy still just 10 per cent of global GDP. ${ }^{6}$ Therefore it simply cannot yet have the same quantitative significance. Second, the much-discussed 'rebalancing' that many analysts have argued is essential for the future sustainability of the Chinese economy is currently under way, but it is predominantly in terms of internal rather than external rebalancing. The investment rate declined from the ridiculously high 48 per cent in 2011 to 44 per cent in 2016, while China's current-account surplus fell from a peak of more than 10 per cent of GDP in 2007 to only 2 per cent in 2011 - a very marked decline. ${ }^{7}$ But since 2013, current-account surpluses have started rising again - not because of more exports but because imports have decelerated or declined faster. Further, since 2014 China's current-account surpluses rose even more sharply with the developing world than with rich countries, as imports from those countries declined at a faster rate. Therefore, while the rebalancing may be important from the longer-run perspective of Chinese growth, it does not necessarily bode well for developing countries. Third, the recovery in China after 2009 has been heavily based on debt, with debt ratios rising for every major category: households, businesses, banks and the government (including central and provincial governments). Credit intensity in China (the new credit associated with an additional unit of GDP) has increased from an average of around 1 in the decade before the global crisis to around 3 in the period 2010-2016. While China is dissimilar to purely capitalist economies that have experienced credit-driven bubbles because of the size and spread of its state-owned banking sector, this extent of excessive leveraging obviously cannot continue beyond a point, and the unwinding of these liabilities can have negative consequences for both growth and stability unless carefully managed.

6. Based on World Bank World Development Indicators online, accessed 12 November 2017.

7. Data calculated from CEIC China database. 
All of this suggests that China cannot play the role of driver of economic growth in other countries in precisely the same way that it did for much of the 2000s; a new strategy is required. There is some evidence that such a new strategy is indeed being considered by the Chinese government - and it has been suggested that the strategy is in effect a twentyfirst century version of the twentieth century Marshall Plan through which the United States provided generous funds to enable the recovery and reconstruction of Western Europe. This is expressed in various initiatives, including the regional and plurilateral projects like the New Development Bank of the BRICS countries and the Asia Infrastructure Investment Bank, but most of all through the ambitious Belt and Road Initiative (henceforth BRI).

The plan of that initiative is certainly ambitious. Harking back to the 'Silk Route' that was established two millennia earlier and became the primary trading route linking the Chinese empire with other civilisations of the time, it aims to connect more than 60 countries with around two-thirds of the world's population. This would be done through infrastructure establishing transport and other connectivity links, facilitating trade and investment, and other forms of cooperation, with China as the hub rather than just one end of the trail (Cai 2017). The stated Chinese perception is that this will rebalance the global economy and restore faith in globalisation through 'new demand created by increasing supply', in a somewhat startling assertion of the much-discredited Say's law at a global level. ${ }^{8}$

The initiative is confusingly named, since the 'Belt' refers to physical roads and overland transport, while the 'Road' actually refers to maritime routes. The Belt covers three main sets of connections, seeking to link China to Russia and the Baltic European countries through Central Asia and Russia; going through Central Asia to connect China with the Middle East, the Persian Gulf and the Mediterranean countries; and establishing seamless transport links between China and Southeast Asia, South Asia and the Indian Ocean. The Road is being described as the ' 21 st Century Maritime Silk Road', which would develop the links of Chinese coastal ports to Europe through the South China Sea and Indian Ocean; and to the countries of the South Pacific Ocean through the South China Sea. Six specific 'international cooperation economic corridors' have been identified to start with. These are: New Eurasia Land Bridge; China-Mongolia-Russia, China-Central Asia-West Asia, China-Indochina Peninsula, China-Pakistan, and Bangladesh-China-India-Myanmar. Each of these corridors is hugely ambitious in terms of the new infrastructure required and the physical and political difficulties of the terrain sought to be covered. Each of them also requires developing particular regions in China in ways that would further these links, which would help to reduce regional inequalities within China. The corridors typically require not just railways and roads, but airports and sea ports, oil and gas pipelines, power transmission routes with cooperation in creating and maintaining regional grids, cross-border optical fibre connectivity, and so on.

For example, the New (or Second) Eurasia Land Bridge Economic Corridor includes an international railway line running from Lianyungang in Jiangsu province on China's eastern coast through Alashankou in Xinjiang Province of west China all the way to Rotterdam in Holland. The China section of the line comprises the Lanzhou-Lianyungang Railway and the Lanzhou-Xinjiang Railway and stretches through eastern, central and western China. Thereafter, it would pass through Kazakhstan, Russia, Belarus and Poland, going through various coastal ports in Europe before terminating at Rotterdam. The plan is not only to offer rail-to-rail freight transport along the entire route, but also eventually to move towards the convenience of 'one declaration, one inspection, one cargo release' for any cargo transported. Considering that this seamless freight transport is still not possible even after the trade facilitation agreement of the WTO, this clearly involves very bullish

8. See http://english.gov.cn/archive/publications/2015/03/30/content_281475080249035.htm. 
expectations about reducing/eliminating customs and border inspection across the participating countries - and relates only to the railroad part of the plan for this particular economic corridor. Other corridors cover more contested and even insecure terrain. ${ }^{9}$

A bigger question is over the financing of this ambitious set of projects. To start with, the funds are largely expected to come from the various development financing initiatives that China has been involved in leading during the past few years. The Asia Infrastructure Investment Bank has a capital of $\$ 100$ billion, nearly half of which comes from China. The New Development Bank of the BRICS countries similarly has a capital base of $\$ 100$ billion. But both of these institutions would lend to a range of projects in different countries, not just those connected to the BRI. In addition, the Silk Road Fund set up exclusively for the BRI by China has $\$ 40$ billion. These are, however, still trivial amounts compared to the scale of the investment required for these grand plans, which would amount to several trillion dollars over the coming few years to meet the declared goals. Indeed, it is still smaller than the current levels of investment in other developing countries enabled by the China Development Bank and the China Eximbank. Clearly, therefore, other sources of funding will be required, which will depend upon commitments and investment guarantees made by the governments of other countries involved as well as the inclinations of private parties, who are notoriously hesitant and fickle with respect to infrastructure investment.

At one level, this seems like a smart and logical move on the part of the Chinese government, given the Chinese economy's current overcapacity in basic and infrastructure industries. It would enable higher capacity utilisation of these industries within China, provide more and larger markets for a range of its output, develop some of its own less prosperous regions, and simultaneously extend its economic and political influence over a wider geographical area. Comparisons to the US Marshall Plan are inevitable, but the basic similarity is only in the recognition of the advantages of such investment in other countries given the mutual dependence on demand generation. In other crucial features - the speed, the scale and degree of generosity of the funding - the BRI does not quite measure up to that earlier effort. The likely investments will be less significant relative to the size of the host economies; the time period over which these are being envisaged is fairly long and so will not generate immediate dramatic impacts; and the amount of expected co-financing required in several projects makes them much less generous or cheap for the recipient countries.

Most significantly, while the Marshall Plan was developed in a context of greater state regulation of markets (of goods, labour and capital) in the postwar period and also consciously recognised the need for income and asset redistribution, the BRI has no such aims. At least on the surface, the Chinese BRI strategy appears to have bought into several features of neoliberal globalisation, including deeper financial integration, protection of various kinds for private investors through 'investment facilitation' and very extensive trade liberalisation that are proposed for all the partner countries in this initiative. This is surprising, since China's own development success has been based on a much more heterodox and state-controlled approach. So it may generate some growth in partner countries,

9. For example, the China-Pakistan Economic Corridor (slated to extend from Kashgar in Xinjiang Province of China to Gwadar port in southern Pakistan) has already become a bone of contention between China and India. It is the chief reason that India stayed away from the inauguration of the BRI in May 2017, since it involves a road being built through Pakistan-occupied Kashmir, recognised by India as being part of its own territory illegally occupied by Pakistan (over which several wars have been fought). That concern in turn has affected prospects for the last corridor, even though Bangladesh and Myanmar are apparently enthusiastic about the potential for enhancing internal and cross-border transport infrastructure in this manner. 
but it will also accentuate inequalities. And, if such an approach does indeed become the norm, then the BRI and similar strategies would not be enough to meet the challenge of injecting demand into the world economy in a way that would save global capitalism from itself.

\section{CHALLENGES FOR THE DEVELOPMENT PROJECT}

What does all this in turn mean for the development project? And what exactly does development consist of? Obviously, there can be many varying definitions for what is essentially an attempt to capture human and social progress. These have ranged from just looking at rising per capita income to more complex and multi-dimensional ideas of human development as the progressive realisation of human rights, or of capabilities, of development as freedom, and so on. In this discussion the focus is on a more specific and limited indicator, on the basis of the argument that the diversification of productive structures in the economy towards higher value-added activities is the essential basis for economic development. Therefore, development is here defined in a more restrictive way, simply as productive transformation, in which industrialisation in particular is extremely important in the early stages.

Development defined in this manner, as output growth combined with structural transformation of both output and employment, has been less common than might be expected. While there has been much talk of income convergence during the period of globalisation, the more striking fact is how limited such convergence has been. Over the past half-century, among developing regions, only the East Asian region has succeeded in coming close to bridging the per capita income gap with advanced countries, and even in this region, relatively few countries have succeeded to any substantial extent. By 2015, the first tier Newly Industrialising Countries (South Korea, Taiwan province of China, Singapore and Hong Kong) had achieved per capita incomes (measured in purchasingpower parity (PPP) exchange rates) of 80 percent of US incomes, but even the spectacular growth of China, as the next most successful, had left it at only 30 per cent of US per capita income (and half of that in market exchange rates). Southeast Asia showed per capita incomes at 20 per cent of the US average, and South Asia only 10 per cent - all measured in PPP terms that tend to overstate the income of the poorer countries. ${ }^{10}$ Meanwhile, Latin America and Sub-Saharan Africa both showed average per capita incomes, which were smaller relative to the US, than they had half a century earlier, while for the Middle East and North Africa there was no real change (UNCTAD 2016). The phenomena of stalled industrialisation and premature de-industrialisation are widespread among developing countries (ibid.), and typically even more evident for employment than for output shares. This hardly describes a substantial spread of development across the globe.

What explains limited per capita income convergence and relative absence of structural transformation in the developing world? One important reason is the increasing concentration of global production and distribution networks, which has been widely noted (UNCTAD 2017). This is related to the proliferation of global value chains (GVCs), which have enabled some expansion of task-specific industrial activities in many countries, but generally to a limited extent only, since they do not necessarily assist broad-based industrialisation (Milberg/Winkler 2013). A significant part of the reason why GVCs do not lead to a greater geographical spread of income is because they are heavily skewed towards firms based in the Global North in terms of profits and other returns. This in turn is largely the result of stringent enforcement of intellectual property rights and the

10. See Ghosh (2018) for an elaboration of this argument. 
monopolies over knowledge that create high profits and monopoly rents in the preproduction stage (design, etc.) and post-production stage (branding and marketing, etc.). Meanwhile, incomes of both workers and their employers in the production stage tend to be reduced by increasingly fierce global competition, which extends across geographical areas to pit workers in both advanced and developing countries against one another. As a result, GVCs have been associated with a 'race to the bottom' in wages and working conditions in particular stages of production and assembly, with women workers and those already experiencing other forms of discrimination often the worst affected. Meanwhile, the nature of international financial flows in the context of still largely deregulated financial markets means that domestic savings need not finance domestic investment even in poor, capital-scarce economies. Before the global crisis, there was a net flow of financial resources from South to North for several years; and this is still true of several emerging markets notwithstanding their current difficulties (UNCTAD 2015). This has implications for growth because current-account surpluses associated with capital flows imply lower rates of investment than could be financed through domestic savings, which has significant implications for countries whose development project is incomplete.

Inter-country income inequalities account for only around half of global inequality by most estimates (Milanovic 2016; Chancel et al. 2018). A large and growing element of the inequality stems from internal economic inequality, which is expressed not only in rising Gini coefficients of assets, incomes and consumption expenditure, but in nearuniversal declines in wage shares of national income (Stockhammer 2015; ILO 2017). The global competition unleashed in the sphere of production has had its most direct effect on the bargaining power of workers everywhere, but this process has also been assisted by policies of labour-market deregulation and 'flexibilisation' within countries. Meanwhile, macroeconomic policies have also operated to generate more economic inequality. The inability or unwillingness to tax the rich (whether individuals or corporations) has led to fiscal policies that reduce demand, because of the pressures for fiscal consolidation that then lead to austerity packages and cutting public expenditure. As a result, there is a lack of public policy focus on good quality employment creation, social protection and delivery of basic needs. As noted earlier, the burden of generating some growth is then put on monetary and financial policies that enable credit bubbles that are inherently unsustainable. Both sets of policies add to inequality, and also inhibit positive structural transformation.

In this context, what are the prospects for development now that global capitalism is showing so much less dynamism? There have been divergent views on whether global stability assists or impedes the development project. It has already been noted that developing countries still remain strongly 'coupled' with advanced economies, at one level suggesting that their fortunes are directly intertwined. Indeed, it has generally been perceived that both economic and geopolitical stability have been beneficial if not essential for the process of development. It is obvious that stability dramatically increases the possibilities of expansion of trade both within and across nations, and this is also suggested by the long-term trends in both trade and economic development across the more advanced nations (Maddison 2001). Stability also provides a more secure and predictable environment for investment, including cross-border investment, that can assist in 'big push' development strategies. It has also been argued that as countries are enabled to engage in more internal and external commerce, the resulting enhanced material well-being of their population feeds back into incentives for ensuring such peace and stability within and across borders. At the international level, such stability has been ensured in certain phases through the presence of a global 'leader' economy that has fulfilled Kindleberger's three functions of discounting in crisis, counter-cyclical credit and market for distress exports (Kindleberger 1996). 
All this then enables countries to make use of the advantages of extending division of labour and specialisation.

But it would be facile to propose that such stability has come about easily or naturally or even that it has been all that frequent or prolonged in global terms. In the phases when it did occur, it has most often been the outcome of violence, generating an imposed order that may have provided some stability, but at the cost of unequal outcomes for different sections of humanity. Findlay/O'Rourke (2009: xviii) argue that 'the greatest expansions of world trade have tended to come not from the bloodless tatonnement of some fictional Walrasian auctioneer but from the barrel of a Maxim gun, the edge of a scimitar, or the ferocity of nomadic horsemen'.

The possibility of unequal outcomes means that such stability may not always be what is necessary or desirable for all countries, particularly those at the bottom of global income ladders. In fact, it may actually serve to cement existing unequal divisions of labour in various ways, and the historical evidence suggests that it has often operated in this way. The most critical element of this process is that of increasing returns (both static and dynamic) that do much to ensure that those countries that are able to create more increasing returns activities faster are more likely to dominate over others, even in a context of supposedly 'free' trade on a 'level playing field' (Reinert 2007). 'Stable' international economic contexts privilege economies that already have larger increasing returns industries and create dynamic processes of greater differentiation over time. It is even possible to argue that such stability itself could well be the result of the differences across regions with varying levels of development, in particular the possibility of pushing adjustments on to some regions and countries (Patnaik 1997) so that there can be relatively crisis-free and non-inflationary growth in the capitalist core. To the extent that global 'stability' is both a cause and an effect of uneven development, capitalism as an international system would need such inequality in order to function smoothly. Essentially, when countries are open to external trade in a world in which increasing returns activities are significant, the chances are greater that such trade will cement existing divisions of labour between countries, because those countries with small or infant industries will be unable to compete with the competition from larger or more advanced industries elsewhere. When these trade patterns get disrupted, either through conscious commercial policies in some countries or because of other factors (such as wars, global recessions, and so on) then there are greater chances of some countries breaking out of the existing division of labour to diversify into higher value added increasing returns activities.

A corollary of this perspective is that, in contrast to stability that reinforces an existing international division of labour and thereby forces countries and peoples to persist at low levels of income and development, some degree of instability may actually benefit economies that are attempting to improve their relative position in the international division of labour. Past periods of global economic instability - such as the 1930s or the 1970s and 1980s - have also been periods when certain countries in the periphery were able to embark upon or intensify their industrialisation projects. The industrialisation of India, Argentina and some other countries was incipient in the 1930s and thereafter during the Second World War when existing supply chains were disrupted. Similarly, the East Asian and Southeast Asian countries that are today perceived as successful industrialisers were able to increase their shares of global manufacturing exports and improve their economic diversification during the period of global economic turmoil and stagnation in the 1970s and 1980s. So 'instability' in global trade can indeed generate possibilities for industrialisation under certain conditions - although the implications can vary greatly depending upon the domestic economic conditions and policies adopted by such countries. It should also be noted that the mechanism of economic 
integration (or disintegration) being considered here is that of trade rather than financial flows, which have very different outcomes.

So will global instability help development now? In other words, does this mean that the current period of stagnation and even greater propensity to crises that appears to be the fate of global capitalism in the immediate future is one that will once again create favourable conditions for the expansion of economies in the periphery? Unfortunately, that seems less likely than was the case earlier, largely because these countries are now integrated not only through trade but also through finance, and the nature of the domination of finance is such that even when trade patterns allow for greater economic diversification in the periphery, financialisation is likely to inhibit it. There are several reasons why the current instability of global capitalism would not be good news for developing countries without a dramatic change in the economic development strategy they choose to adopt.

First, the context of breakdown or stagnation of trade would enable some structural change in developing countries that are locked into lower value production, but only to the extent that these economies that do not base expansion on exports but on internal markets or at least regional markets. In export-led models, lack of demand becomes a critical constraint - so a different accumulation model would have to be adopted. Second, international financial integration persists and has intensified further after the global crisis. This means that developing countries must face and cope with the volatility of cross-border flows and associated internal instability; loss of independent monetary policy and directed credit; constraints on fiscal policy, especially on expanding public expenditure. It is now well-established that financial liberalisation may lead to 'financial deepening', but it does not necessarily have a positive effect on investment and real economic growth. Rather, it can generate savings that are then exported in the form of capital outflows. This retards productive diversification and exposes the economy to domestic and global boom-bust cycles. Domestic growth then is sustained by consumer credit that fuels housing and real estate booms and finance for related investment. These bubbles usually end in tears, as the unravelling of household and corporate debt has knock-on adverse effects on bank viability and on investment. So liberalised finance - both cross-border and internal - still makes developing economies vulnerable; and global trade slowdown then adds to existing pressures on domestic economies.

Clearly, without significant changes in the orientation and mode of economic policies, the current global instability will not provide any conducive features for development. In this context, how can the development project be revived today? Within nation states, the first point to note is that the export obsession that formed the basis of macroeconomic and development strategies is no longer useful. It is evident that export-led growth has reached its limits, not only because of the stagnation and saturation of Northern markets and the inability of other emerging markets to take up the slack, but because of the ongoing explosion of protectionist tendencies in different parts of the world. Therefore, the focus has to be on domestic wage- and employment-led growth, rather than relying on short-run expansions based in credit. The need for an investment push still remains critical, and usually requires active state intervention in different forms. In all of this, it is important to remember that manufacturing still matters, even though increasingly the process of encouraging manufacturing activity must factor-in ecological considerations. Further, the policy focus on large-scale enterprises can be detrimental, especially if it is not accompanied by significant policy attention to small producers, especially those in agriculture. Internal inequality is an important reason for inadequate domestic markets, so asset and income inequality have to be addressed not only for better social welfare, but also for macroeconomic reasons. There is huge potential for more revenues from direct taxation, particularly by plugging loopholes that allow and even encourage tax evasion and tax avoidance. This must also be accompanied by more effective 
regulation of both capital and labour markets, including activities of multinational companies, and to ensure decent working conditions. Related to this, it is important to control finance: to prevent periodic crises, reduce vulnerability and direct credit to priority activities. Finally, social policy should be seen as an integral part of development policy, since the universal provision of good quality basic goods and services and focus on care work are not only important for better quality of life, but also ensure bottom-up demand generation over smoother economic cycles, provide more employment, ease the various pains and tensions that are inevitable in the process of industrialisation, and thereby enable a more sustainable development trajectory.

All this requires international cooperation - but if not that, at least less external pressure from global rules and global institutions that prevent these policies. In other words, if the world economy is to be put on a more stable footing that enables expansion and some income convergence, revisions to domestic economic policies must be accompanied by changes in the architecture that currently governs international trade and finance, to reduce the power of large private capital.

\section{REFERENCES}

BIS (Bank for International Settlements) (2008): Annual Report, Basel: Bank for International Settlements.

BIS (Bank for International Settlements) (2010): Annual Report, Basel: Bank for International Settlements.

Cai, P. (2017): Understanding China's belt and road initiative, Analysis document, Lowy Institute for International Policy, URL: https://www.lowyinstitute.org/sites/default/files/documents/ Understanding\%20China\%E2\%80\%99s\%20Belt\%20and\%20Road\%20Initiative_WEB_1.pdf Chancel, L., Piketty, T., Saez, E. (2018): World Inequality Report, Paris: The Inequality Lab.

Findlay, R., O'Rourke, K.H. (2009): Power and Plenty: Trade, War, and the World Economy in the Second Millennium, Princeton, NJ: Princeton University Press.

Ghosh, J. (2010): Global crisis and beyond: sustainable growth trajectories for the developing world, in: International Labour Review, 149(2), 209-225.

Ghosh, J. (2018): A note on estimating income inequality across countries using PPP exchange rates, in: The Economic and Labour Relations Review, 29(1), 24-37.

Gutman, J., Sy, A., Chattopadhyay, S. (2015): Financing African infrastructure: can the world deliver? Report, Washington, DC: Brookings Institution, URL: https://www.brookings.edu/wpcontent/uploads/2016/07/AGIFinancingAfricanInfrastructure_FinalWebv2.pdf.

ILO (International Labour Office) (2017): Global Wage Report 2016-17, Geneva: International Labour Office.

Kindleberger, C. (1996): Economic Primacy, 1500-1990, New York: Oxford University Press.

Maddison, A. (2001): The World Economy: A Millennial Perspective, Paris: OECD Development Centre.

Milanovic, B. (2016): Global Inequality: A New Approach for the Age of Globalization, Cambridge, MA: Harvard University Press.

Milberg, W., Winkler, D. (2013): Outsourcing Economics: Global Value Chains in Capitalist Development, New York: Cambridge University Press.

Patnaik, P. (1997): Accumulation and Stability under Capitalism, Oxford: Clarendon Press.

Reinert, E. (2007): How Rich Countries Got Rich, and Why Poor Countries Stay Poor, London: Constable.

Stockhammer, E. (2015): Rising inequality as a cause of the present crisis, in: Cambridge Journal of Economics, 39(3), 935-958.

UN (United Nations) (2006): World Economic Situation and Prospects, New York: United Nations.

UNCTAD (United Nations Conference on Trade and Development) (2008): Trade and Development Report 2008: Commodity Prices, Capital Flows and the Financing of Investment, Geneva: United Nations. 
UNCTAD (United Nations Conference on Trade and Development) (2010): Trade and Development Report 2010: Employment, Globalisation and Development, Geneva: United Nations.

UNCTAD (United Nations Conference on Trade and Development) (2014): Trade and Development Report 2014: Global Governance and Policy Space for Development, Geneva: United Nations.

UNCTAD (United Nations Conference on Trade and Development) (2015): Trade and Development Report 2015: Making the International Financial Architecture Work for Development, Geneva: United Nations.

UNCTAD (United Nations Conference on Trade and Development) (2016): Trade and Development Report 2016: Structural Transformation for Inclusive and Sustained Growth, Geneva: United Nations.

UNCTAD (United Nations Conference on Trade and Development) (2017): Trade and Development Report 2017: Beyond Austerity: Towards a Global New Deal, Geneva: United Nations. 